\title{
Epidemiology of human leptospirosis in Saint Lucia, 2010-2017
}

\author{
Gemma Chery, ${ }^{1}$ Lorraine Francis, ${ }^{2}$ Shelly-Ann Hunte, ${ }^{3}$ and Phil Leon ${ }^{1}$
}

Suggested citation Chery G, Francis L, Hunte S-A, Leon P. Epidemiology of human leptospirosis in Saint Lucia, 2010-2017. Rev Panam Salud Publica. 2020;44:e160. https://doi.org/10.26633/RPSP.2020.160

ABSTRACT Objective. To describe the epidemiology of human leptospirosis cases in Saint Lucia from 2010 to 2017 and determine whether there was a relationship between cases and rainfall and temperature.

Methods. A retrospective analytical study was undertaken to describe the seasonal patterns of human leptospirosis cases reported to the Ministry of Health of Saint Lucia between 2010 and 2017. Confirmed cases of leptospirosis were analyzed according to age, sex, seasonality, and geographical distribution. Disease incidence was calculated and the association of cases with geographical distribution, rainfall, and temperature was investigated.

Results. A total of 353 leptospirosis cases were reported between 2010 and 2017 and of these, 145 (40.6\%) were laboratory confirmed. Cases were aged 7 to 73 years (mean 34 years; median 30 years) with a male to female ratio of $4.2: 1$. Six deaths were reported during the period, with an overall case fatality rate of $4.1 \%$. There was no relationship between location (district) and incidence of leptospirosis in Saint Lucia. There was a weak correlation between rainfall and leptospirosis cases during the 8-year period $\left(r_{\mathrm{s}}=0.25, p=0.015\right)$ but the correlation between cases and seasons was not statistically significant (dry season $r_{\mathrm{s}}=0.13, p=0.42$; wet season $\left.r_{\mathrm{s}}=0.23, p=0.08\right)$. There was no correlation between leptospirosis cases and temperature $\left(r_{\mathrm{s}}=0.07\right.$, $p=0.49)^{s}$.

Conclusions. Leptospirosis has a seasonal distribution in Saint Lucia, with outbreaks during periods following increased rainfall and flooding, such as in the aftermath of tropical storms and hurricanes. Saint Lucia and other Caribbean countries should enhance surveillance for leptospirosis given the likelihood of increased flooding following frequent and intense rainfall due to climate change.

Keywords Leptospirosis; Saint Lucia; Caribbean Region.

Leptospirosis, a re-emerging zoonotic disease, is globally regarded as an increasing public health problem $(1,2)$. The annual morbidity rate in the Caribbean is estimated at 50.7 per 100000 population (3). It mostly occurs in tropical and subtropical countries and is caused by the pathogenic bacteria leptospira (4). Most mammalian species are natural carriers of pathogenic leptospires (4-6), which when excreted in urine into the environment, are able to survive in soil and water for prolonged periods $(6,7)$. Humans become infected through contact with contaminated materials such as urine from carrier animals, water, or wet soil (5). Severity of illness is broad and can range from asymptomatic, to mild, non-specific self-limiting febrile illness, to severe multiorgan failure associated with high mortality (8). Nonspecific signs present similarly to other diseases including dengue fever, malaria, and influenza, often leading to delayed or missed diagnoses (6).

Leptospirosis has been identified in several countries in the Caribbean $(9,10)$ and human cases have been reported in Saint Lucia since 1992 (11). From 1992 to 2017 , a total of 668 cases were reported to the Ministry of Health's Epidemiology Unit, with

\footnotetext{
1 Ministry of Health and Wellness, Castries, Saint Lucia $\square$ Gemma Chery, slugems@yahoo.com
} 
$52 \%$ of cases $(n=353)$ reported during 2010 to 2017 (12). Disease surveillance data show a gradual increase in the reporting of leptospirosis from 1992 onwards. This increase may either be due to disease emergence or improved disease surveillance, or both. Overall, average disease incidence was 1.4 cases per 100000 population for the period 1992-2000, 3.2 cases per 100000 population for 2001-2009, and 10.6 cases per 100000 population for 2010-2017 (12).

Climatic conditions such as rainfall and flooding and temperature have been shown to be key drivers of leptospirosis transmission (4). Global warming due to climate change could potentially increase disease burden through increased flooding and greater survival time of leptospires in the environment, posing a significant health risk for humans. Several studies have shown a positive correlation between laboratoryconfirmed cases and rainfall and temperature (13-16). In Saint Lucia, several outbreaks of leptospirosis were reported following floods, subsequent to Hurricane Tomas (a category 2 storm) in 2010, a Christmas Eve trough in 2012, extensive rainfall during the years 2011 and 2013, Tropical Storm Matthew in 2016, and Hurricane Maria (a category 2 storm) in 2017 (12). Although there are studies that examined leptospirosis in some Caribbean countries, there are few which evaluated the role of climate-specifically, precipitation and temperature-on the incidence of human leptospirosis. The objectives of this study were to provide an epidemiological description of human leptospirosis cases reported in Saint Lucia during 2010-2017 and to determine whether cases were associated with rainfall and temperature.

\section{MATERIALS AND METHODS}

\section{Study area}

Saint Lucia, a mountainous Small Island Developing State (SIDS) of the Windward Islands in the Caribbean, is located northeast of Saint Vincent and the Grenadines, northwest of Barbados, and south of Martinique. Given its geographical location, Saint Lucia is vulnerable to tropical storms and hurricanes and usually experiences flooding following intense rainfall events. The country is a member of the Organization of Eastern Caribbean States (OECS), a 10-member grouping of islands which together form a near-continuous archipelago across the eastern reaches of the Caribbean Sea. Saint Lucia covers a land area of $620 \mathrm{~km}^{2}$ (17) and has a population of 174777 inhabitants (18). Administratively, the island is divided into eight municipalities: one city and seven health districts. Weather across the island is homogeneous, with a dry season occurring generally from January to June, and a rainy season typically from July to December.

\section{Case data}

Cases were characterized as outlined in the National Surveillance Manual. A suspected case was defined as any person who presented with three or more of the following symptoms: fever $\left(\geq 38{ }^{\circ} \mathrm{C}\right)$, headache, myalgia of calves and/or thighs, conjunctival suffusion, meningitis, or jaundice. A confirmed case was characterized as a case with the signs and symptoms of leptospirosis and a positive enzyme-linked immunosorbent assay (ELISA) IgM test (titers of $\geq 1: 640$ ).

\section{Data collection}

Leptospirosis is a notifiable communicable disease in Saint Lucia. The Epidemiology Unit within the Ministry of Health is responsible for gathering reports of cases from hospitals and private physicians on a weekly basis. Case data are collected using case reporting forms with questions about demographic information and clinical manifestations. For this retrospective analytical study, data from all single and outbreak (years 2010, 2011, 2013, and 2017) leptospirosis cases from 1 January 2010 to 31 December 2017 were extracted from the communicable disease database for analysis. Daily rainfall and temperature data are routinely collected at meteorological stations located at the George F. Charles Airport in the north and the Hewanorra International Airport in the south of the island by the Caribbean Institute for Meteorology and Hydrology. These data were used to calculate Saint Lucia's average daily and average monthly temperature and rainfall for our analysis. Annual estimated mid-year population data were obtained from the Central Statistical Office of the Ministry of Economic Development, Housing, Urban Renewal, Transport and Civil Aviation and used for calculating disease incidence.

\section{Data analysis}

All data obtained were treated as confidential. Patient identifier information was removed and the data were coded for analysis. Descriptive analysis was performed using Microsoft Excel and SPSS version 22. Since population data disaggregated by sex and age were not available, age- and gender-standardized analyses of these variables were not performed. Incidence by health district and year were calculated based on the number of laboratory-confirmed cases per 100000 population. Annual case fatality rates were calculated by dividing the number of deaths by the number of laboratory-confirmed cases for each of the years included in our review. Association of cases with geographical distribution was tested using the Kruskal-Wallis method. Laboratory-confirmed cases that occurred between January and June each year were classified as "dry season" while cases that occurred between July and December were classified as "wet season." As the data were not normally distributed, Spearman's rank correlation was used to assess association between seasons and leptospirosis cases, and temperature and leptospirosis cases during the 8-year review period. A $p$-value of $<0.05$ was used to indicate statistical significance of the results obtained.

\section{RESULTS}

\section{Geographical distribution}

For the period 2010-2017,353 suspected cases of leptospirosis were recorded by the Epidemiology Unit, Ministry of Health. Of these, $145(40.6 \%)$ were laboratory confirmed from eight health districts. Disease incidence ranged from 36.3 cases per 100000 population in Gros Islet to 263.8 cases per 100000 population in Anse-la-Raye (Figure 1). Overall incidence was 83.0 cases per 100000 population. There was no correlation between leptospirosis cases and geographical distribution during the 8 -year review period (Kruskal-Wallis $=7.00,7$ degrees of freedom, $p$-value $=0.429$ ). 
FIGURE 1. Human leptospirosis incidence per 100000 population, by health district, Saint Lucia, 2010-2017

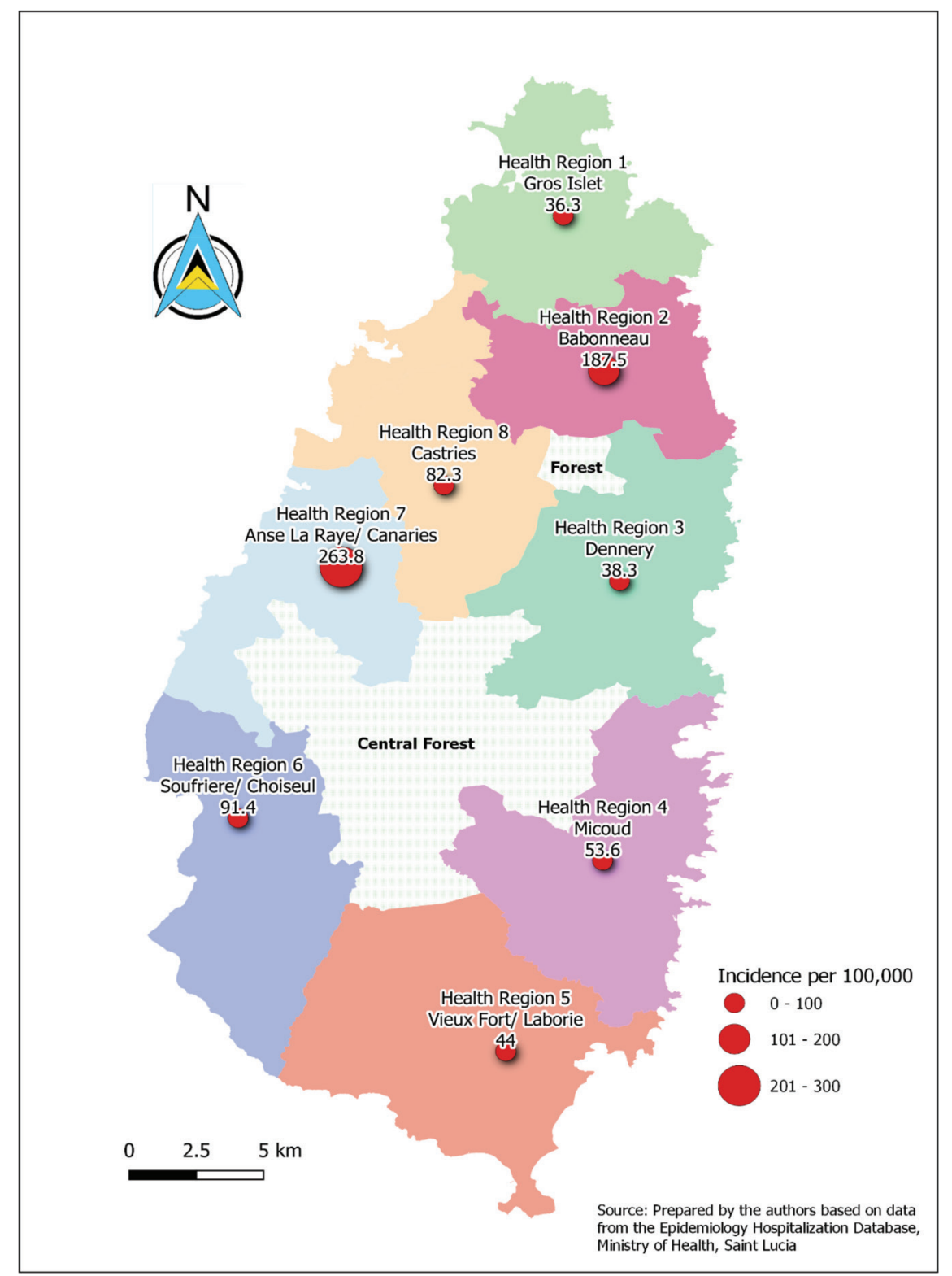

\section{Seasonality and incidence of leptospirosis}

The timing of the transmission cycle was generally similar for each year, with the cycle beginning in July following the start of the wet season. The lowest incidence occurred during March to June, with an increased number of cases recorded from July to November. The highest incidence was observed during the months of December and January (Figure 2). A second peak in cases was observed in September. Overall, a higher proportion of cases was observed during the wet season (July to December), at $71 \%$ $(p<0.001)$. This pattern was noted for all the years except 2014 .

The lowest annual incidence was recorded in 2015, at 4.6 cases per 100000 population, and the highest in 2011, at 17.9 cases per 100000 population. For the 8-year period, the mean annual incidence was 8.3 cases per 100000 population.
There was a weak correlation between rainfall and leptospirosis cases during the 8-year review period $\left(r_{\mathrm{s}}=0.25\right.$, $p=0.015)$. This correlation was not statistically significant when performed by season (dry season $r_{\mathrm{s}}=0.13, p=0.42$; wet season $\left.r_{\mathrm{s}}=0.23, p=0.08\right)$. There was no correlation between leptospirosis cases and temperature $\left(r_{\mathrm{s}}=0.07, p=0.49\right)$.

\section{Sex, age, and mortality}

Of the 145 laboratory-confirmed cases, 81\% were male $(n=117)$ and $19 \%(n=28)$ were female. Each year, the number of males diagnosed with leptospirosis was higher than the number of females, with an overall male to female ratio of 4.2:1. Six deaths were recorded during the period, with an overall case fatality rate of $4.1 \%$. All deaths were among males. The highest 


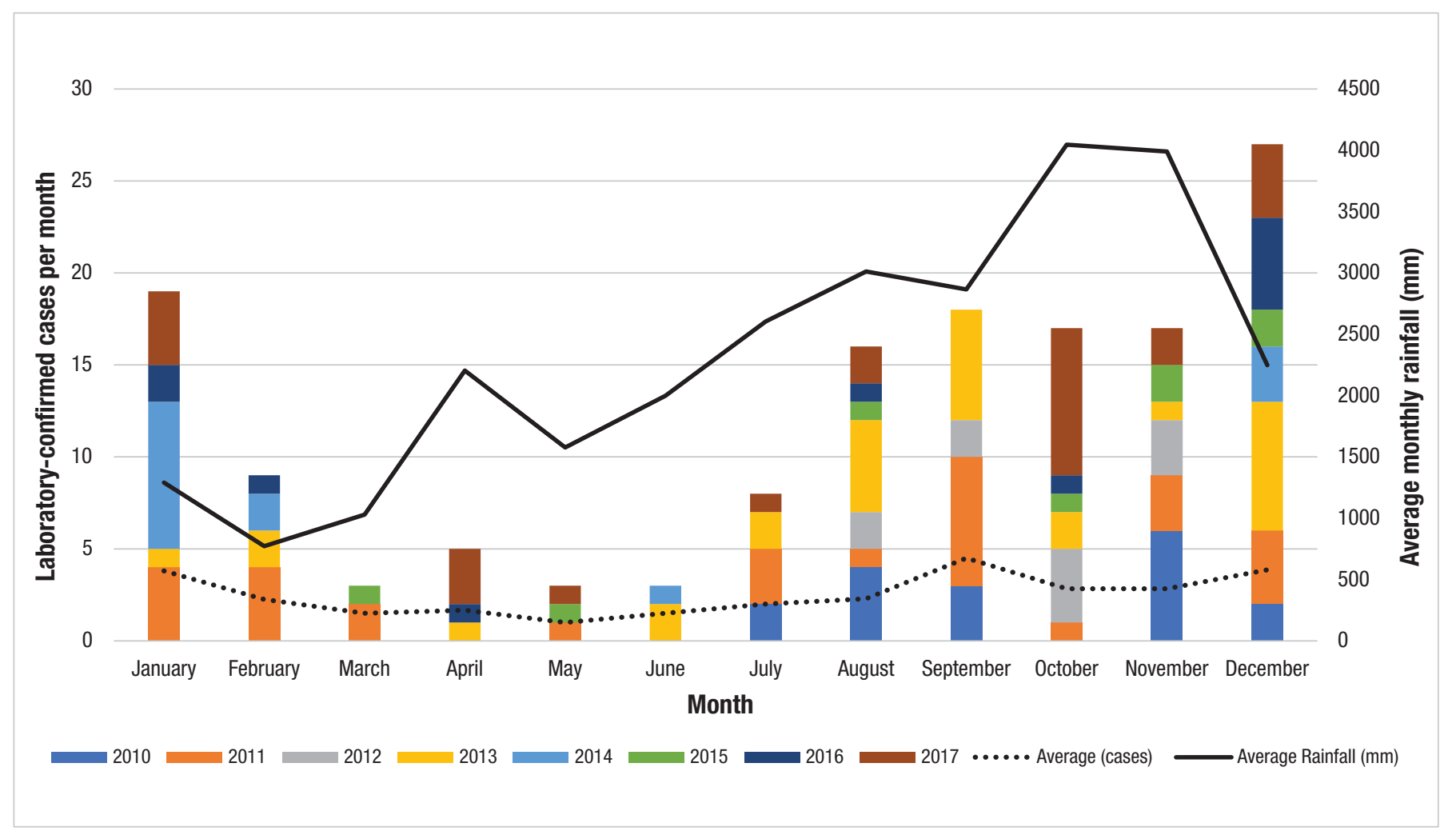

Source: Prepared by the authors based on data from the Ministry of Health and the Caribbean Institute for Meteorology and Hydrology.

case fatality rate was in $2011(n=3,10.0 \%)$ followed by 2016 $(n=1,9.1 \%)$. One death each was recorded for 2010, 2016, and 2017. No deaths were recorded from 2012 to 2015 (Table 1).

Cases were aged 7 to 73 years (mean 34 years, median 30 years). Overall, the age group with the highest number of cases was $20-29$ years $(n=42,29 \%)$, and $47 \%$ of all cases were in age groups 10-19 and 20-29 years combined ( $n=69,47.6 \%$ ). The lowest number of cases were among children aged 9 years or under $(n=2,1.4 \%)$ (Figure 3$)$.

\section{DISCUSSION}

Since the first human leptospirosis cases were reported in Saint Lucia in 1992, the number of cases has substantively increased. From our results, the mean annual incidence rate of leptospirosis in Saint Lucia during the 8-year review period was 8.3 per 100000 population. This result is comparable with the rates of 12.0 per 100000 population in Trinidad and Tobago, 10.0 per 100000 population in Barbados, and 7.8 per 100000 population in Jamaica, the three countries with the highest leptospirosis incidence in the Caribbean (19). As has been observed in many developing countries, the incidence of leptospirosis is increasing, with small tropical islands generally having the highest incidence of infection (20). This increase is likely correlated with population growth, urbanization, and climate change.

In relation to geographical distribution, data from our review suggest that there was no relationship between location (district) and incidence of leptospirosis in Saint Lucia.
The greatest incidence of cases occurred in Anse-la-Raye, a district that can be characterized as rural, located on the western coast from the capital Castries. Anse-la-Raye, the district with the highest poverty gap on the island (21), is the home to mainly fishermen and agricultural workers. Although information on occupation types was not available for inclusion in this analysis, occupations that involve contact with fresh water, soil, rodents, or cattle have been shown to be high risk factors for leptospirosis disease $(22,23)$. While there is no official urban/rural disaggregation in Saint Lucia, Anse-la-Raye fits the criteria for local classification as a rural community. The United Nations Statistics Division recommends that this classification be left to individual countries to develop (24); therefore, the association between the increased occurrence of leptospirosis in rural settings can be made. While persons living in rural communities have been shown to be at greater risk of becoming infected, exposure of the general population to high seasonal rainfall and associated flooding likely contributes to increased risk (25).

Based on our findings, leptospirosis in Saint Lucia is a seasonal disease with more cases occurring in the latter months of the wet season. This finding is consistent with previous observations made in the Caribbean $(19,25,26)$. The Atlantic hurricane season runs from 1 June to 30 November within the rainy season. Tropical storm and hurricane formation increases in August, with peak storm formation in the month of September. Continuous rain over several days during the rainy season along with land saturation contributes to the collection of pools 
TABLE 1. Laboratory-confirmed leptospirosis cases and deaths, by sex, Saint Lucia, 2010-2017

\begin{tabular}{|c|c|c|c|c|c|c|c|c|c|}
\hline \multirow[t]{2}{*}{ Year } & \multicolumn{2}{|c|}{ Male } & \multicolumn{2}{|c|}{ Female } & \multirow[t]{2}{*}{ Total no. } & \multirow[t]{2}{*}{ M:F ratio } & \multicolumn{2}{|c|}{ Deaths } & \multirow{2}{*}{$\begin{array}{c}\text { Case fatality rate } \\
(\%)\end{array}$} \\
\hline & No. & Percentage & No. & Percentage & & & Male & Female & \\
\hline 2010 & 16 & $94 \%$ & 1 & $6 \%$ & 17 & 16 & 1 & 0 & $5.9 \%$ \\
\hline 2011 & 23 & $77 \%$ & 7 & $23 \%$ & 30 & 3.3 & 3 & 0 & $10.0 \%$ \\
\hline 2012 & 9 & $82 \%$ & 2 & $18 \%$ & 11 & 4.5 & 0 & 0 & $0.0 \%$ \\
\hline 2013 & 19 & $66 \%$ & 10 & $34 \%$ & 29 & 1.9 & 0 & 0 & $0.0 \%$ \\
\hline 2014 & 13 & $93 \%$ & 1 & $7 \%$ & 14 & 13 & 0 & 0 & $0.0 \%$ \\
\hline 2017 & 21 & $84 \%$ & 4 & $16 \%$ & 25 & 5.3 & 1 & 0 & $4.0 \%$ \\
\hline Total & 117 & $81 \%$ & 28 & $19 \%$ & 145 & 4.2 & 6 & 0 & $4.1 \%$ \\
\hline
\end{tabular}

Source: Prepared by the authors based on data from the Ministry of Health.

FIGURE 3. Distribution of laboratory-confirmed leptospirosis cases by age and sex, Saint Lucia, 2010-2017

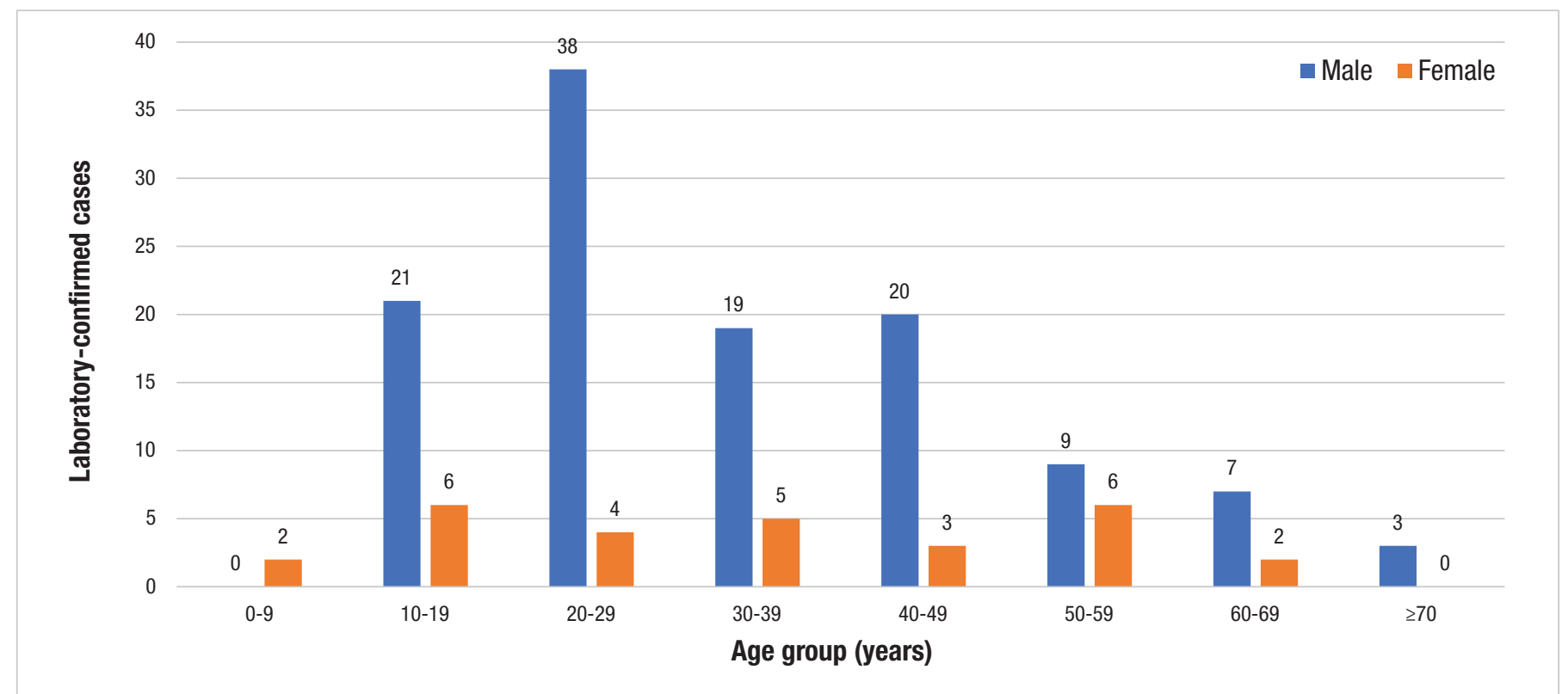

Source: Prepared by the authors based on data from the Ministry of Health.

of water, which facilitate survival of leptospires in the environment. Drainage channels in the valleys along with the extensive network of associated natural river systems are intensively used by people for domestic, farming, and recreation use. Disease incidence is therefore generally higher during the wet season when flooding occurs. In Saint Lucia, flooding occurs each year mainly on the western coast of the island. The frequency of intense rainfall events and tropical cyclones is increasing and consequently the occurrence of flooding episodes. This is due to urbanization, destruction of forested areas and wetlands, and climate change (3). Tropical storms and hurricanes are expected to become more frequent and intense due to climate change, as demonstrated by the occurrence of category 5 hurricanes during the past four consecutive Atlantic hurricane seasons (2016-2019). Interestingly, however, a weak correlation between the number of leptospirosis cases and rainfall was observed, despite it being a risk factor associated with leptospirosis.
This could be explained, in part, by the small number of cases reported each year. Future work to examine human leptospirosis cases in the OECS (which includes Saint Lucia) to determine whether cases are associated with rainfall and temperature may improve study robustness.

Leptospirosis cases occurred in all age groups, with the majority of cases occurring between 10 and 29 years of age. This age group includes students and young people more likely to be actively engaged in recreational activity. Approximately four times as many cases were among males than females. The occurrence of more cases of leptospirosis and deaths in males than in females is in keeping with other reports, both regionally and elsewhere $(3,10,19,27)$. Higher case numbers in males are likely attributable to greater frequency and duration of exposure through occupational/recreational activities among males than females (4). Public health actions based on reducing occupational/recreational exposure, predominantly among males, 
would be important if the higher occurrence of cases in males can be attributed to occupational/recreational exposure.

\section{Limitations}

This work has some limitations. First, although leptospirosis is notifiable in Saint Lucia, cases are reported via passive surveillance. It is therefore likely that cases with mild illness may have been missed by the system and so were not included in this analysis. Second, leptospirosis is often misdiagnosed as dengue fever in dengue-endemic regions, and so there is the likelihood that laboratory tests for leptospirosis may not have been performed for these cases. Third, confirmed cases were identified as those yielding a positive ELISA IgM test (titers of $\geq 1: 640$ ) in addition to signs and symptoms of the disease. The IgM ELISA, while widely used to support leptospirosis testing, can yield inaccurate results. IgM antibodies can persist for many months, yielding false positive results when trying to identify current infection; conversely, IgM antibodies cannot be detected in the early stages of leptospirosis infection, yielding false negative results. Nevertheless, the data we used were the best available for conducting this retrospective analytical study.

\section{Conclusion}

Leptospirosis has a seasonal distribution in Saint Lucia, with outbreaks during the wet season, which corresponds to periods following increased rainfall and flooding; for example, in the aftermath of tropical storms and hurricanes. As Small Island Developing States are likely to continue to experience increased temperatures, rainfall events, and flooding, leptospirosis surveillance, prevention, and control should be given more priority by public health professionals—especially during the wet season.
Integrated surveillance involving human health, animal health, and environmental health, disease mapping and spatiotemporal modeling would be useful for estimating current disease burden and predicting future disease burden. These should be adopted to aid public health professionals in understanding key risk factors for the disease and the actions required to reduce risks. Educational programs should be directed to flood-prone and vulnerable communities to make them more aware of the disease and preventive actions that can be taken to avoid infection. National laboratory capacity should also be strengthened to support leptospirosis surveillance, given that disease incidence is likely to continue to increase as a result of climate change.

Author contributions. GC conceived the idea, acquired the data, and drafted the manuscript. LF, SAH, and PL performed data analysis and drafted the manuscript. All authors reviewed and approved the final version.

Acknowledgments. The authors thank the staff of the Ministry of Health of Saint Lucia for their work in the collection of the data for this study. The authors also thank the Caribbean Institute for Meteorology and Hydrology for providing rainfall and temperature data, which contributed to part of the analysis in this study.

Conflicts of interest. The authors declare no conflict of interest. The authors declare no financial interest in the subject matter disclosed.

Disclaimer: Authors hold sole responsibility for the views expressed in the manuscript, which may not necessarily reflect the opinion or policy of the RPSP/PAJPH and/or the Pan American Health Organization (PAHO).

\section{REFERENCES}

1. Hartskeerl RA, Collares-Pereira M, Ellis WA. Emergence, control and re-emerging leptospirosis: dynamics of infection in the changing world. Clin Microbiol Infect. 2011;17(4):494-501. https://doi. org/10.1111/j.1469-0691.2011.03474.x

2. Abela-Ridder B, Sikkema R, Hartskeerl RA. Estimating the burden of human leptospirosis. Int J Antimicrob Agents [Internet]. 2010 [cited 2020 Mar 17];36 Suppl 1:S5-S7. https://doi.org/10.1016/j. ijantimicag.2010.06.012

3. Costa F, Hagan JE, Calcagno J, Kane M, Torgerson P, Martinez-Silveira MS, et al. Global morbidity and mortality of leptospirosis: a systematic review. PLoS Negl Trop Dis. 2015;9(9):e0003898. https:/ / doi.org/10.1371/journal.pntd.0003898

4. Levett PN. Leptospirosis. Clin Microbiol Rev. 2001;14(2):296-326. https:/ / doi.org/10.1128/CMR.14.2.296-326.2001

5. World Health Organization. Human leptospirosis: guidance for diagnosis, surveillance and control. Geneva: WHO; 2003:33-8. Available from: https://apps.who.int/iris/handle/10665/42667

6. Bharti AR, Nally JE, Ricaldi JN, Matthias MA, Diaz MM, Lovett MA, et al. Leptospirosis: a zoonotic disease of global importance. Lancet Infect Dis. 2003;3(12):757-71. https://doi.org/10.1016/ S1473-3099(03)00830-2

7. Mwachui MA, Crump L, Hartskeerl R, Zinsstag J, Hattendorf J. Environmental and behavioural determinants of leptospirosis transmission: a systematic review. PLoS Negl Trop Dis. 2015;9(9):e0003843. https://doi.org/10.1371/journal.pntd.0003843
8. Glynn K, Hartskeel R, Ko A, Meslin F. Leptospirosis. In: Heymann DL, editor. Control of communicable diseases manual. 19th ed. Washington DC: American Public Health Association; 2008. p. 351-7.

9. Petrakovsky J, Bianchi A, Fisun H, Nájera-Aguilar P, Pereira MM. Animal leptospirosis in Latin America and the Caribbean countries: reported outbreaks and literature review (2002-2014). Int J Environ Res Public Health. 2014;11(10):10770-89. https://doi.org/10.3390/ ijerph111010770

10. Adesiyun AA, Baboolal S, Suepaul S, Dookeran S, Stewart-Johnson A. Human leptospirosis in the Caribbean, 1997-2005: characteristics and serotyping of clinical samples from 14 countries. Rev Panam Salud Publica. 2011;29(5):350-7. Available from: https://iris.paho. org/bitstream/handle/10665.2/9529/a08v29n5.pdf

11. Caribbean Epidemiology Centre. Annual report 1992. Port-of-Spain: CAREC; 1993

12. Saint Lucia, Ministry of Health and Wellness. Leptospirosis reports: unpublished; 2017.

13. Ehelepola NDB, Ariyaratne K, Dissanayake WP. The correlation between local weather and leptospirosis incidence in Kandy district, Sri Lanka from 2006 to 2015. Glob Health Action. 2019;12(1):1553283. https://doi.org/10.1080/16549716.2018.1553283

14. Desvars A, Jégo S, Chiroleu F, Bourhy P, Cardinale E, Michault A. Seasonality of human leptospirosis in Reunion Island (Indian Ocean) and its association with meteorological data. PLoS ONE. 2011;6(5):e20377. https:/ /doi.org/10.1371/journal.pone.0020377 
15. Sumi A, Telan EFO, Chagan-Yasutan H, Piolo MB,Hattori T, Kobayashi $\mathrm{N}$. Effect of temperature, relative humidity and rainfall on dengue fever and leptospirosis in Manila, the Philippines. Epidemiol Infect. 2017;145(1):78-86. https://doi.org/10.1017/s095026881600203x

16. Batchelor TWK, Stephenson TS, Brown PD, Amarakoon D, Taylor MA. Influence of climate variability on human leptospirosis cases in Jamaica. Clim Res. 2012;55:79-90. https://doi.org/10.3354/cr01120

17. Pan American Health Organization. Health in the Americas+, 2017 edition. Summary: Regional outlook and country profiles. Washington, DC: PAHO; 2017. Available from: https://iris.paho.org/ handle/10665.2/34321

18. Saint Lucia, Ministry of Economic Development, Housing, Urban Renewal, Transport and Civil Aviation, Central Statistical Office. Community Population 2016. Internal ministry report: unpublished; 2016.

19. Mohan ARM, Cumberbatch A, Adesiyun AA, Chadee DD. Epidemiology of human leptospirosis in Trinidad and Tobago, 1996-2007: a retrospective study. Acta Trop. 2009;112(3):260-5. https://doi. org/10.1016/j.actatropica.2009.08.007

20. Pratt N, Rajeev S. Leptospira seroprevalence in animals in the Caribbean region: a systematic review. Acta Trop. 2018;182:34-42. https:/ / doi.org/10.1016/j.actatropica.2018.02.011

21. Kairi Consultants Limited. Saint Lucia national report of living conditions 2016: final report. 2018 December 7. Available from: https:/ / www.stats.gov.lc/wp-content/uploads/2019/01/Saint-LuciaNational-Report-of-Living-Conditions-2016-Final_December-2018.pdf

22. Barragan V, Olivas S, Keim P, Pearson T. Critical knowledge gaps in our understanding of environmental cycling and transmission of leptospira spp. Appl Environ Microbiol. 2017;83(19):e01190-17. https:/ / doi.org/10.1128/AEM.01190-17

23. Sethi S, Sharma N, Kakkar N, Taneja J, Chatterjee SS, Banga SS, et al. Increasing trends of leptospirosis in northern India: a clinico-epidemiological study. PLoS Negl Trop Dis. 2010;4(1):e579. https://doi. org/10.1371/journal.pntd.0000579

24. United Nations Statistics Division [Internet]. Population density and urbanization. New York: UNSTATS; c2017 [cited 2020 Apr 17] Available from: https://unstats.un.org/unsd/demographic/sconcerns/densurb/densurbmethods.htm\#B

25. Peters A, Vokaty A, Portch R, Gebre Y. Leptospirosis in the Caribbean: a literature review. Rev Panam Salud Publica. 2017;41:e166. https://dx.doi.org/10.26633\%2FRPSP.2017.166

26. Herrmann-Storck C, Brioudes A, Quirin R, Deloumeaux J, Lamaury I, Nicolas M, et al. Retrospective review of leptospirosis in Guadeloupe, French West Indies 1994-2001. West Indian Med J. 2005;54(1):42-6. https://doi.org/10.1590/s0043-31442005000100009

27. McGrowder D, Brown P. Clinical and laboratory findings in patients with leptospirosis at a tertiary teaching hospital in Jamaica. Res Rep Trop Med. 2010;1:59-64. https:/ / doi.org/10.2147/RRTM.S14118

Manuscript received on 9 December 2019. Revised version accepted for publication on 6 May 2020 


\section{Características epidemiológicas de la leptospirosis humana en Santa Lucía, 2010-2017}

RESUMEN Objetivo. Describir las características epidemiológicas de los casos de leptospirosis humana en Santa Lucía entre el año 2010 y el año 2017, y determinar si hubo un vínculo entre el número de casos, las precipitaciones y la temperatura.

Métodos. Se llevó a cabo un estudio analítico retrospectivo para describir el patrón estacional de los casos de leptospirosis humana notificados al Ministerio de Salud de Santa Lucía entre el año 2010 y el año 2017. Los casos confirmados de leptospirosis se analizaron según la edad, el sexo, el carácter estacional y la distribución geográfica. Se calculó la incidencia de la enfermedad y se evaluó la relación entre el número de casos y la distribución geográfica, las precipitaciones y la temperatura.

Resultados. Se notificaron 353 casos de leptospirosis entre el 2010 y el 2017, entre ellos, 145 (40,6\%) casos confirmados mediante pruebas de laboratorio. Los casos se presentaron en personas de 7 a 73 años (media de 34 años; mediana de 30 años) con una razón hombre:mujer de 4,2:1. Se notificaron 6 muertes durante el mismo período y una tasa de letalidad general de 4,1\%. No se encontró un vínculo entre la ubicación (distrito) y la incidencia de la leptospirosis en Santa Lucía. Se estableció una correlación débil entre las precipitaciones y el número de casos de leptospirosis durante el período de 8 años $\left(r_{\mathrm{s}}=0,25, p=0,015\right)$; la correlación entre el número de casos y las estaciones no fue estadísticamente significativa (estación seca, $r_{\mathrm{s}}=0,13, p=0,42$; estación húmeda, $\left.r_{\mathrm{s}}=0,23, p=0,08\right)$. No se estableció una correlación entre el número de casos de leptospirosis y la temperatura $\left(r_{s}=0,07, p=0,49\right)$.

Conclusiones. La leptospirosis presenta una distribución estacional en Santa Lucía, con brotes que surgen tras períodos de aumento de las precipitaciones e inundaciones; por ejemplo, después de tormentas y huracanes tropicales. Santa Lucía y otros países del Caribe deben mejorar la vigilancia de la leptospirosis dado que el cambio climático aumenta la probabilidad de inundaciones tras períodos de precipitaciones frecuentes e intensas.

Palabras clave Leptospirosis; Santa Lucia; Región del Caribe.

\section{Epidemiologia da leptospirose humana em Santa Lúcia, 2010-2017}

RESUMO Objetivo. Descrever a epidemiologia dos casos de leptospirose humana em Santa Lúcia de 2010 a 2017 e determinar se houve uma relação entre a ocorrência de casos e precipitação e temperatura.

Métodos. Um estudo retrospectivo analítico foi realizado para descrever o padrão sazonal dos casos de leptospirose humana notificados ao Ministério da Saúde de Santa Lúcia entre 2010 e 2017. Os casos confirmados de leptospirose foram analisados por idade, sexo, sazonalidade e distribuição geográfica. A incidência da doença foi calculada e a associação entre a ocorrência de leptospirose e distribuição geográfica dos casos, precipitação e temperatura foi pesquisada.

Resultados. Ao todo, 353 casos de leptospirose foram registrados entre 2010 e 2017. Destes, 145 (40,6\%) tiveram confirmação laboratorial. Os casos ocorreram em indivíduos entre 7 e 73 anos de idade (média 34 anos; mediana 30 anos) com uma proporção de 4,2:1 entre os sexos masculino e feminino. Houve seis mortes durante o período estudado, com uma taxa de letalidade global de 4,1\%. Não foi verificada uma relação entre localização geográfica (distrito) e incidência de leptospirose em Santa Lúcia. Foi observada uma fraca correlação entre a ocorrência de casos e precipitação no período considerado de 8 anos $\left(r_{\mathrm{s}}=0,25, p=0,015\right)$, mas a correlação entre casos da doença e estações do ano não foi estatisticamente significativa (estação seca $r_{\mathrm{s}}=0,13, p=0,42$; estação chuvosa $\left.r_{\mathrm{s}}=0,23, p=0,08\right)$. Não foi verificada correlação entre leptospirose e temperatura $\left(r_{s}=0,07, p=0,49\right)$.

Conclusões. A leptospirose tem distribuição sazonal em Santa Lúcia, com a ocorrência de surtos nos períodos que se seguem ao aumento da precipitação e às enchentes, como após tempestades tropicais e furacões. Santa Lúcia e os outros países do Caribe devem intensificar a vigilância da leptospirose diante da possibilidade de maior ocorrência de enchentes com as chuvas intensas e mais frequentes decorrentes da mudança climática.

Palavras-chave Leptospirose; Santa Lúcia; Região do Caribe. 